（V）选水續行，第二次侵蝕層は更に厚さを貲加する。
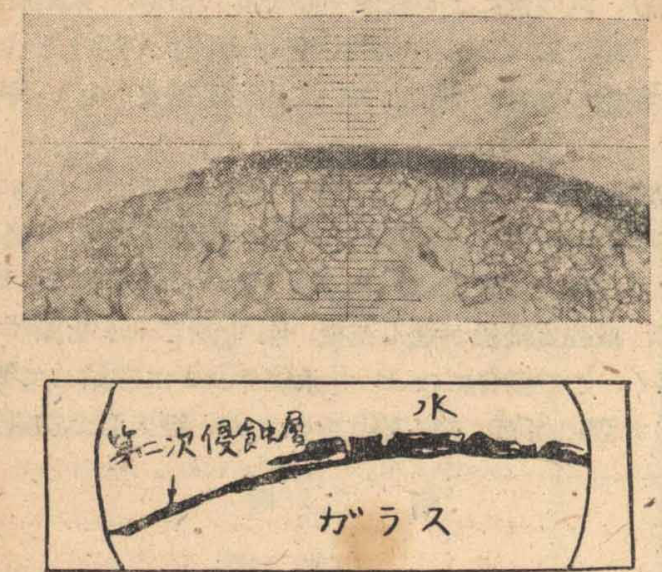

溫度は兩者共 $80^{\circ} \mathrm{C}$ である. 水中に於て生ずる嵬裂と, 乾燥の際生

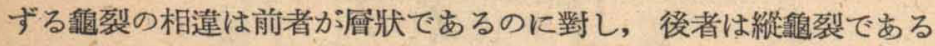
事である. 㒶狀皒裂の生成により侵蝕速度が急增する事は前報に詳 述した。縱㦹裂は表面に附着して居た水が消失すると同時に多數生 じ，薄膜は小部分に別れ，乙かも表面は先に乾燥する瓷第 3 圖(III) (說明圖)に圖示した樣に歪曲し，逐に脫落する. 假令末侵蝕部に猶 懸吊してるても再び水に浸漬すれば直ちに剝落し，水中に流れ去る. (V). もし水に連續的に浸漬した临觀測すれば前報第 2 圖に示した 樣に鍟狀龜裂のみ生じ層の厚さが約 $300 \mu$ 位になる迄は薄膜は㓥落 する事は無い.

理酸薄膜の線收縮は, 縱鼠裂の間酇の幅から推察して, 脫落前て 大咯 $5 \%$ 程度で可成り大きい。

\section{考察}

侵蝕㾦に二種の龜裂が生ずる理由に就て考察する. 一般に膜の冈 部に生ずる歪力は膜面に切線方向をなすものと垂直方向をなすもの があるが膜が薄い、場合には薄膜面に切線方向をなす゚もののみを考へ れば良い，膜が膨脹する際には膜內に娾縮力が，收縮する際には膜 內に張力が生じ， 又之によつて薄膜と，薄膜が覆ふ基體の境界には 剪斷力が生ずる.薄膜の抗張力及び抗㕍力が大であれば，剪斷力に
(VI) (V) 撮影後直ちに再び流れを断ち加燃空氣を这入す, 第一次侵蝕層は既に膯落視野に無く第二次侵蝕厤に艇裂の 生咸が認められる。

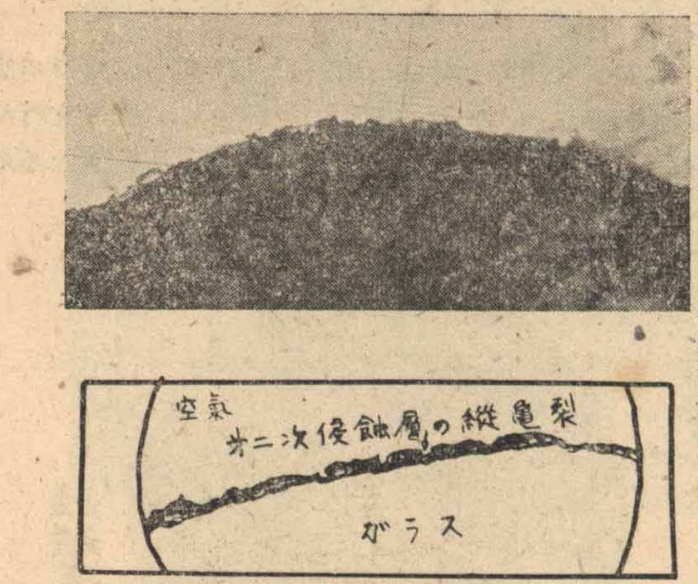

よつて薄膜と基體の境界には亡りによる鼠裂郎ち 層狀龜裂が生じ， 逆の場合には薄膜自體が破壞する. 抗張力は抗原力に比し逥かに弱 いのが普通であるから，薄膜が收縮する場合には，剪㫁力によつて 境界に層狀龜裂が生ずる゙前に，薄膜內部に縱の䶟裂が入り易い.以

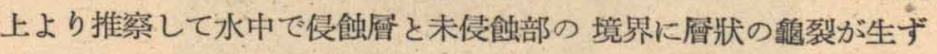
るのは, ガミスからアルカリが溶出し之に代つて水分子を件ふ水素 イオンが撗散により侵大, 薄膜が水和膨潤する結果であり, 㕛乾燥 の際膜薄に縱䶟裂の入るのは水分の蒸發による收縮の結 果と考へら れる. 郎ち水中では薄膜の膨潤により剝裂 (Shivering) が生じ, 乾 燥の際には水分の蒸㗶により裂鋍 (Craging) が生じるのであらう.

水分の蒸發による收縮は甚だ大きく, 女表面から蒸發する鳥歪曲

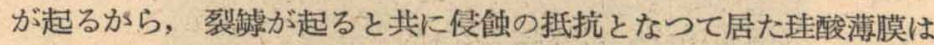
殆んど脫落する.水をガラスに連續的に作用させる時より,時々乾燥 させた方が侵蝕作用の甚だしいのは之が 1.つの原因と考へられる.

裂鐻の發生は既に長枝氏 (前出)，J. Marwedell (Glasfafrikationsfehler)により認められて居り，之が侵蝕作用に及ぼす影響に關す る長枝氏の上述の推定は著者等が面接觀察した結果と良く一致す る.

終りに臨み本研究について種々御呚示を賜つた大阪工業試驗所高 松博士はじめ研究所各位に對し厚く感謝の意を表する.

\title{
光學ガラスの化學的耐久性に關する基礎的研究（第 $\mathbf{4}$ 報）
}

\author{
水中に於てガラス表面に生じた珪酸薄膜が剥裂 \\ する場合の活性化エネルギーの算出に就て
}

\author{
澤井郁太郎・田 代 ‘仁・梅 屋 墨
}

Untersuchungen über die chemische Widerstandsfähigkeit der optischen Gläsern.

(IV) über die Aktivierungsenergie beim Lösungsvorgang im Wasser.

Von Ikutaro Sawai, Megumi Tashiro t; Kaoru Umeya.

緒 言

著者等は $\mathrm{Na}_{2} \mathrm{O}_{2 \cdot 2} \mathrm{SiO}_{2}, \mathrm{Na}_{2} \mathrm{O}_{8} \mathrm{SiO}_{2}$ ガラスの水中に於ける溶解現
象を研究し，侵蝕速度が時折急增するのはガラ゙ス表面に生成した理 酸に富む薄膜と未侵蝕部の境界に於ける原狀䳼裂の 發生が原因であ る事を顯微鏡下゙で確認し，之を前報に報告した·光學ガラスの水文は 
酸への溶解に際しても同樣な現象が起る事は躰に E. Berger(Glastech. Ber. 1934, 12, 189) 土橋正二氏 (物理化學の進步，昭 18，17， 105) 等によつて推察されて居り, 又長岡正男氏が BK 7, BaK 4 等 のガラスに就て示された水中に長時間侵漬する場合の溶解曲線つ暴 常な形狀 (Glastgch. Ber. 1937, 17, 327〜329), 及び長枝春本氏が 高バリウム鉆系ガラスに就て得られた溶解曲線の階段的形狀 (工化, 昭 18,46,326) 等も, ガラス溶解中, 生成薄膜に何等かの變化が起 る事を示唆するものと考へられる．斯かる溶解現象を考察する事は "複雜な光學ガラスの化學的耐久性を究明する上に 極めて必要である と思はれるので本報にはその 1 として水中に於てガラス表面に生じ た珠酸薄膜が剝裂する場合の活性化エネルギーの算出に關する若干゙ の考察を述ぺた。

\section{1. 從來の文獻}

ガシスが化學的侵蝕を受ける場合の活性化ェネルギー Q は從來 G. Geffcken (Glastech. Ber. 1938, 16, 296 304; Kolld. Z. 1939, $86,11$. ) 森谷太郎氏 (工化, 昭 $15,43,884$ ), 長枝春平氏 (工化, 昭 $18,46,6)$, 土橋正二氏 (前出) 等により求められ，その算出には次 式が使用されてるる。

$$
\begin{aligned}
& \operatorname{lnS}=\mathrm{A}-\mathrm{Q} / \mathrm{RT} \\
& \text { 但L. } \mathrm{R} \text { : 氣體恒數 } \\
& \mathrm{T}: \text { 絕對溫度 } \\
& A: \text { 常數 }
\end{aligned}
$$

式中 S は研究者によつて異り, G. Geffcken 氏はアルカリ溶液に よるガラス侵蝕速度 (侵蝕の進み/時間) を, '森谷氏は水中に溶出し， たアルカリ量を, 長枝氏は酸の侵蝕によつて生じた䔳膜がある厚さ に達する迄の時間 $t$ を, 土橋氏は反應速度恒數 $k$ (但し $f$ を珠酸薄 膜の厚さ, $t$ を時間, $k^{\prime}$ を常數とする時 $k$ は $f^{2}=k t+k^{\prime}$ により表 はされる)をそれぞれ S の值どして居られる.

G. Geffcken“の研究はアルカリ溶液を使用するもので, ガラス表 面に侵蝕の抵抗となる薄膜は生成しないから, 他の研究及び本報に 於て取披ふガラスの酸及び水中への溶解とその機構を異にする.

森谷氏は上式を始めて理論的に誘導され， $\mathrm{E}$ はガラス表面より分 子 (森谷, 前出 888 頁) が溶出するに要する最小のエネルギー（之 を溶出エネルギーと名附けられた) である事を指摘されたが，その 考察は薄膜に䗍裂が起ら極く初期の場合に適用されるものである (森谷, 前出 886 頁).

2. 薄膜が生成する場合の活性化エネルギーの算出

特殊なガラス（例一ば前報の $\mathrm{Na}_{2} \mathrm{O} \cdot \mathrm{SiO}_{2}$ ガラス等）を除いて, 一 般にガラスが水によつて侵蝕を受ける場合には，ガラス表面に珪酸 に富む溥膜が生成し，この薄膜を通過して水中に逃出する易溶性成 分 (例一ばアルカリイオン) と水中より逆に侵大する水分子又は水 素イオンの相互擴散速度により侵蝕速度は支配される. (前出).

今ガラス溶解の途中, 薄膜の性質が變化せず, 又溶出物質が蒖膜 表面から水によつて直ちに取去られる場合を考へるならば Fick の 第二法則から次式が成立する。

$$
m^{2}=\text { const. } D t \ldots \ldots \ldots \ldots \ldots \ldots \ldots \text { (1) }
$$

但し $m$ は溶出した易溶性成分の量, $t$ は時間， $D$ は膜中に於ける 相互撗散恒數である.

薄膜中に於ける擴散物質の濃度勾配が直線をなす場合には溶出量 と侵蝕層厚 (薄膜の厚さ) は比例するから。 $l^{2}=$ const. $D t \ldots \ldots \ldots \ldots \ldots \ldots \ldots$ (2)

嚴密に云へば濃度勾配は直線でないが，之を直線として取报つて も多くの實驗事實を說明する事が出來る.
この式は侵蝕速度が侵蝕層厚の逆數に比例するとの考へからも導 出されるるので, 特殊な場合を除き, ガラスの溶解に於て屡々適用 されてるる (E. Berger.; 長枝; 土橋, 前出).

擴散恒數 D は $\mathrm{e}$

$D=$ const. $e^{-Q / R T}$

により表はされるもので, 之より（2）式は次式となる.

$l^{2}=k, t, \stackrel{\mathrm{e}}{\downarrow}, \mathrm{e}-Q / R T$

(3) 式は理論的に誘導し得る式で, 式中 $Q$ は一般に, “拱散の活 性化エネルギー”と呼ばれる， $R$ は氣體恒數， $T$ は絕對溫度， $\mathrm{k}$ は 恒數である.Qの物理的意味に就ては種㣻の說明が爲されて居るが, H. Braune (Z, Physi. K. Chem. 1924, 110, 147) に從へば, 此處 では熱振動を行つて居る擴散物質の中，この $Q$ より大なるエネルギ 一を有するもののみが薄膜中を擴散出來ると解される. 郎ち $Q$ は搌 散物質が薄膜中を撗散進行するに要する最小のエネルギーである.

（4）式の對數をとり，時間 $t$ が一定な場合を考へれば次式が得ら れる.

$$
\begin{array}{r}
\log l=a-b / T \ldots \ldots \ldots \ldots \\
\quad \text { 但し } b=0.4343 \cdot(Q / 2) / R
\end{array}
$$

$$
\mathrm{a}: \text { 恒數 }
$$

\section{3. 薄膜が剥裂し乍ら侵蝕が進む場合}

前報に於て著者等はガラス表面に生成した 薄膜がある厚さに達す ると薄膜と未侵蝕部の境界に曆狀の龜裂が生ずる事を認め, 之は薄 膜內部の易溶性成分と水素イオンに附隨する 水分子の相互置換によ り薄膜が膨潤する事に起因するずのであると述へた，即ち膨潤によ り薄膜內部に生ずる膜面に 切線方向をなす歪力は, 膜厚の增加と共 に增大し, 之が薄膜と未侵蝕部の剪斷應力に 打勝つに至ると逐に迄 りが生じ所謂舦裂が起る，汇りが生ずる際の 剪斷應力はガラスが同

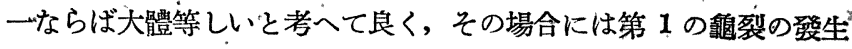
から次に龜裂が生ずる迄の侵蝕の進みも等しい筈である．㙷微鏡下
第 1 圖

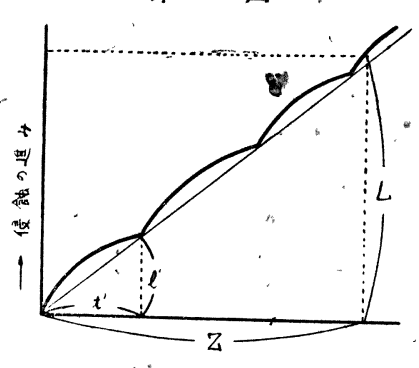

时间一 に於ける觀察の結果では剝裂が 起る迄の個々の侵蝕の進みに就 ては可成りの變動があるが，之 は試料の不均一性其他の原因に よると思はれる. 今侵蝕の進み “がある厚さ l'に達する、時に必 らず剥裂が起る場合を圖示すれ ば第 1 圖の如くで, 剶裂が起る 四數が大なる時には侵蝕の進み $\mathrm{L}$ と時間 $\mathrm{Z}$ の間には近似的に次

式が成立する。

$$
L=l^{\prime}\left(z / t^{\prime}\right) \cdots \cdots \cdots \cdots \cdots \cdots \cdots \cdots \cdots \cdots(6)
$$

$t^{\prime}$ は㓩裂が起る迄の時間である. 然るに $t^{\prime}$ は前述の (4) 式によ り表はされるから，之を（6）式に代大すれば

$$
L=k z_{e} e^{-Q / R T} / l^{\prime} \quad \ldots \ldots \ldots \ldots \ldots \ldots \text {. }
$$

となる. $k, l^{\prime}$ は恒數であり，又時間 $z$ を一定とすれば上式は $\log L=a^{\prime}-b^{\prime} / T \ldots \ldots \ldots \ldots \ldots \ldots(8)$

$$
\text { 但し } b^{\prime}=0.4343 Q / R
$$

$$
a: \text { 恒數 }
$$

となる. (8) 式と（5）式とを比較すれば薄膜が㓥裂する場合にも， 剥裂が起る前と同樣に侵蝕の進みの對數と絕對溫度の逆數との間に は直線關係が成立する事が解る，然し薄膜が剝裂する場合には線の 傾辇は剶裂が起る前の場合の 2 倍である. 


\section{4.＼cjkstart侵蝕の進みと溫度との關係}

ガラスの耐水性をアルカリ溶出量で測定する場合にアルカリ溶出 量 (對數) と㴘度 $(1 / T)$ との關係は $60^{\circ} \mathrm{C}$ 附近で交る 2 直線で與へ られる事は實驗的に確められてるる(森谷, 前出; 田端, 旭化工學研 究報告第 6 輯, 昭 14,190 , 其他). 薄膜中のアルカリの濃度勾配力淔 線をなす場合には侵蝕の進みはアルカリ溶出量と比例するから, 侵 蝕曆の進み $(\log l)$ と溫度 $(1 / T)$ の關係も同樣であるべき筈である.

满膜の剥裂を考虑すれば斯かる 2 直線の出現に對して次の如き說 明が可能である。

今 (4) 式に於て

$Q=20$ calmol $^{-1}$

と假定し (後出), 種々の溫度に於ける侵蝕の進み $l$ と時間 $t$ の關 係を求めると第 2 圖の點線が得られる.之は剝裂の起らぬ場合であ るが，侵蝕の進みが じに達する時, 剝裂が起るとすれば實線の如く になる. 之より種々勾測定時間 $\left(t_{1}, t_{2}, \cdots \cdots t_{8}\right)$ に於ける侵蝕の進み を求め, 次にその對數と絕對溫度の逆數の關俰を求めると第 3 圖に 示寸結果が得られる.

郎ちこの樣な圖式解法から， $t_{3}, t_{4}, t_{5}$ の如き測定時間で賽驗を行ふ 場合には $(\log l)$ と $(1 / T)$ の關係は交る 2 直線で表はされる事が解 る. $t_{1}$ の場合に得られる直線は (5) 式に， $t_{\mathrm{B}}$ の場合に得られる直線 は (8) 式水相當する.

佾上の圖式解法に於て侵蝕の進みは階段狀曲線(嘪線)の平均であ る鎖線（第 2 圖 II, $100^{\circ} \mathrm{C}, 90^{\circ} \mathrm{C}$ に就て示した.(他の曲線では少略し

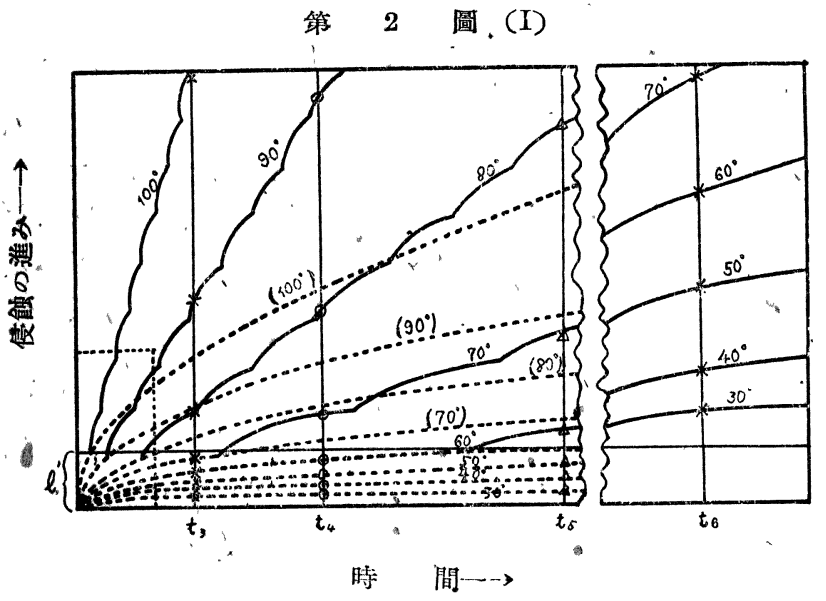

第 2 圖 (II) 第 2 圆 (I) の點線內部を擴大したもの.

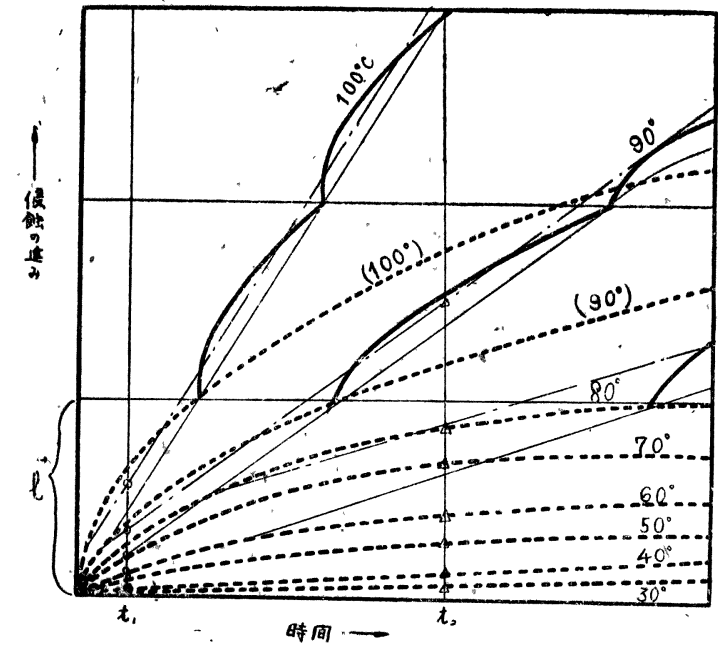

てある.)の值を探つた. 之は粉末法等の測定ではガラス表面の 1 點 に於ける侵蝕よりも各點に於ける侵蝕の本均が問題となり, しかも 各侵蝕點に於ける段階狀曲線は總てが同時刻に屈曲するとは限ら ず, 從つて互に重疊し，實驗結果は之等の平均が出る事を考虑した からである。

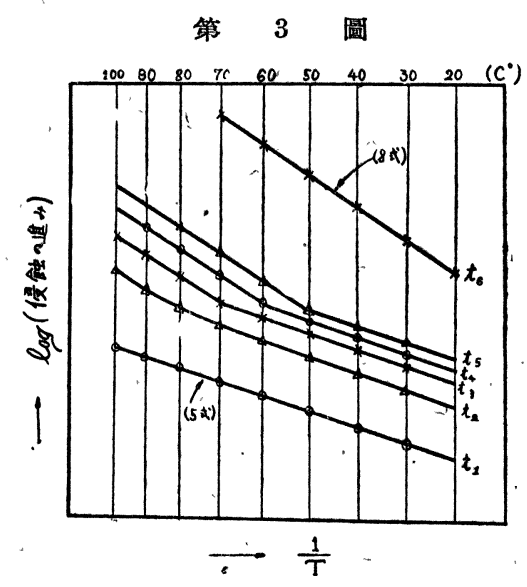

\section{5. アルカリ溶出量より活性化エネルギー を算出する場合}

薄膜中のアルカリの濃度勾配が直線をなす場合には侵蝕の進みは アルカリ溶出量と比例するから 薄膜が剝裂する場合にも, 又剝裂す る前にも（8）又は（5）々同樣な式が成立する．尤も利裂する場合 には，ガラスから遊離した薄膜から佾その中に 殘存寸るアルカリが 溶出寸る事も考虑寸る必要がある，しかし斯かる場合を考慮に大れ ても，(8) 式の $\mathrm{a}^{\prime}$ は異るが $\mathrm{b}^{\prime}$ の值は同一である.

總括

撗散物質が溥膜中を擴散進行するに要するエネルギー（“擴散の 活性化ェネルギー”) を $Q$ とすれば，以上の考察より侵蝕の進み( 又 はアルカリ溶出量）の對數と絕對溫度の逆數との關係は次の如くに なる。

（1）剝裂が生ずる前は直線的關係が得られ，その直線の倾科より 求めたエネルギーは $Q / 2$ である。

（2）剝裂が生じ乍ら侵蝕が進む場合にも直線的關係が得られる。 その直線の傾斜は（1）の場合の 2 倍, 郎ち $Q$ である.

（3）高溫度の侵蝕に於てのみ项裂が生ずる場合には，屈曲した直 線が得られる事もあり，その倾斜は高溫度では（2）の場合に，低溫 度では（1）の場合に相當する。

\section{附 記}

森谷氏（前出）はソーダー 珪酸 2 成分系及びソーダ・硼酸・珪酸 3 成分系に就き, 溶出量の對數と絕對溫度の逆數との關係を求められ, 之が $60^{\circ} \mathrm{C}$ 附近で屈曲した直線で表はされると云ふ,興味ある結果を 得られたが，もし剝裂の生成を考慮すれば（3）の如き說明が可能に 思ばれる。

同氏の得られた属曲愍以下の溶出エネルギーは大體 $10 \mathrm{cal} \mathrm{mol-1}$ であり，(1)より考へれば薄膜中に於ける “攄散の活性化ェネルギ 一"Q はその 2 倍, 郎ち $20 \mathrm{cal} \mathrm{mol}^{-1}$ と考へられる.

土橋氏 (前出) は F2 ガラスに就き “ $20 \mathrm{cal} \mathrm{mol}^{-1}$ なる” 活性化 エネルギー”を得られて居るが，之は反應恒數と溫度の關係より算 出されたもので本報に述べた $Q$ と理諭的に同じ意味を持つものであ る.

第 2 圖の作圖に於て $Q=20 \mathrm{cal} \mathrm{mol}$-1 $^{-1}$ と假定したのは森谷氏，土 橋氏等の實驗結果を考慮した結果である. 